\begin{tabular}{|c|c|c|c|c|c|c|c|c|c|}
\hline \multirow{3}{*}{\multicolumn{2}{|c|}{ 結 核 }} & \multirow[b]{2}{*}{ 肺 } & \multirow[b]{2}{*}{ 切 } & \multirow[b]{2}{*}{ 除 } & \multirow[b]{2}{*}{$\omega$} & \multirow[b]{2}{*}{ 統 } & \multirow[b]{2}{*}{ 計 } & \multirow[b]{2}{*}{ 的 } & 616. 24-089. 87 \\
\hline & & & & & & & & & 観＼cjkstart察 \\
\hline & & & & 第 & 1 & 編 & & & \\
\hline & 主 & & 乙 & 適 & 忍 & 症 & K & $w$ & $\tau$ \\
\hline
\end{tabular}

国立㙩養所山陽茌 (指導: 八塚陽一荘長)

多田邦夫

[昭和 34 年 3 月 28 日受稿]

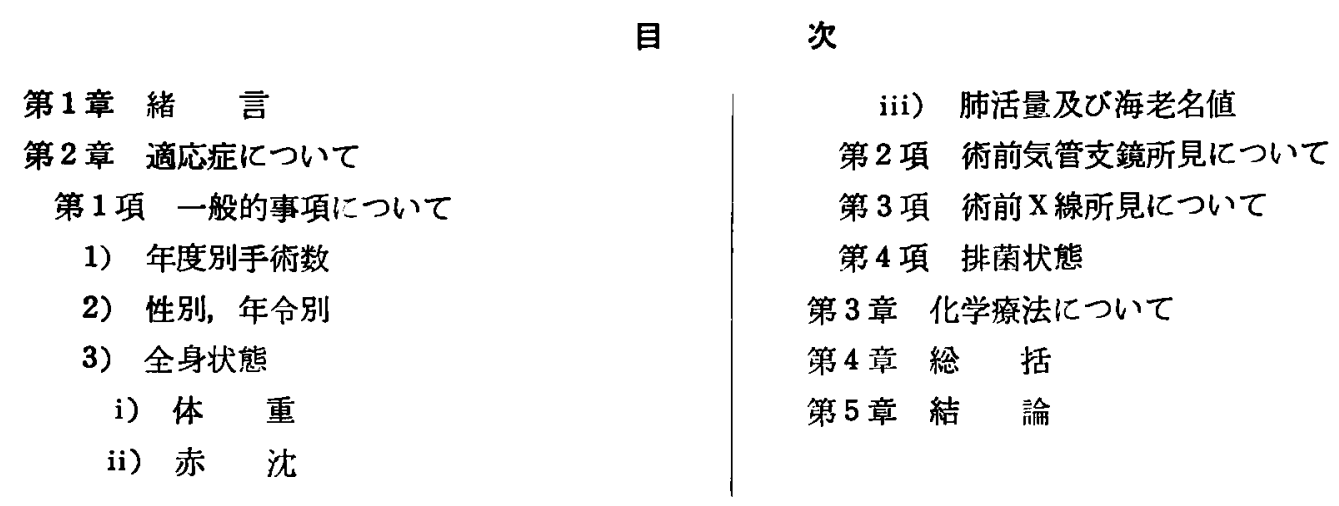

\section{第 1 章 腥言}

肺結核に対しては18世紀前半から急激に発達した 虚脱療法が相当な効果を現わしたが，気管支拡張症 や肺癌には全く効果がみら机ない，すなわち之等に は切除以外治療法がないため，肺切除は先づ気管 支拡張症や胡癌の治療法として発達した。

gluck ${ }^{1)}$ は1881年家兔の肺切除に成功し, 粆物実 験において肺切除が可能であることを示した，人体 に対し最初に肺切除を試みたのは Block2)（1881） であるがこれは不成功に終り，肺結核に対し肺切除 を行つて最初に成功したのは Tuffier (1891) であ る. 続いて Lowson, Doyen3) (1895) 等の成功が 報告されているが，その後は人工気胸術や胸廓成刓 術等虚脱療法の急激な発達に比し, 肺切除術は気 管支搪張や肺癌の治療に用いられ，肺結核の治療之 しては殆んど行われず，細々とした研究が1930年頃 まで続けられている。ややまとまつたものとして 1939年, John Dolly4) 加 5 例の実施例を報告した か，1944年迄には約90例か文献上集められるに過ぎ なかつた。 ての頃より漸次成功例を增す様になると 共に手術例数は急激に増加し，Overholt ${ }^{5)}$, Sweet ${ }^{6}$ ), Bailey (), Mair, Moore, Robert 等により最近に
おける肺切除の基礎が作られた. 殊に1947年以降 Streptomycin を始めとする化学療法の発達，手術 適応の確立, 晽酥法の発達, 大量輸血の実施, 手術 手技の向上等により手術の安全性は高められ合併症 は減少し，時日の経過につれ成績は向上した。

吾か国では大正11年 (1923年) 関口蕃教授により 肺癖の疑で右下菓の部分切除が行われたのが最初で ある。（実際は結節性結核であつた）次いで昭和 12年 (1937年) 小沢教授8) は日本外科学会総会の宿 題報告の中で絬節性結核 1 例, 上葉炎 3 例，計 4 例 の肺結核に対する肺切除について述へた。

その後戦封中は肺切除の研究は殆んど見られず，

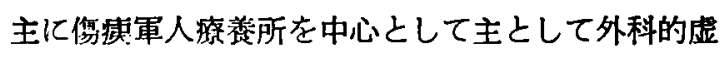
脱療法の研究が行われたが, 病巣の性質, 位置等に よつては全く虚脱療法が無効であるものに屡々遭遇 し，てれに対する不満が増大すると共に米国に於け る肺切除の進歩に刺戟されて, 昭和23年頃より宮本, 鈴木, 幕内, 河合, 箫井等により肺切除の研究が着 手された。

我々は国立療養所山陽註において昭和24年 4 月よ り肺切除を開始し，昭和33年4月現在1700例に達し た. その間適応症, 術前術後の化学療法, 手術法, 後処置等に絶えざる変遷があり，従つて各期におけ 
る手術の意義やその成綪等に多大な相違が存在する 加，現在において一応肺結核治療上における地位は 確立したと考えられ，又併せて将来における本治療 法の価值の確立や発達のために統計的観察を試みる ことは意義あるてとと信ずるので，昭和 32 年 3 月末 までの1350例につき概観的に行つたその結果を発表 する次第である.

第2章 通応症について

\section{1) 年度別手術数}

まず外科療法の推移を虚脱㙩法の代表である胸成 訹と比较すると，図 1 の如くである．胸成術は26年

因 1 外科療法の推移

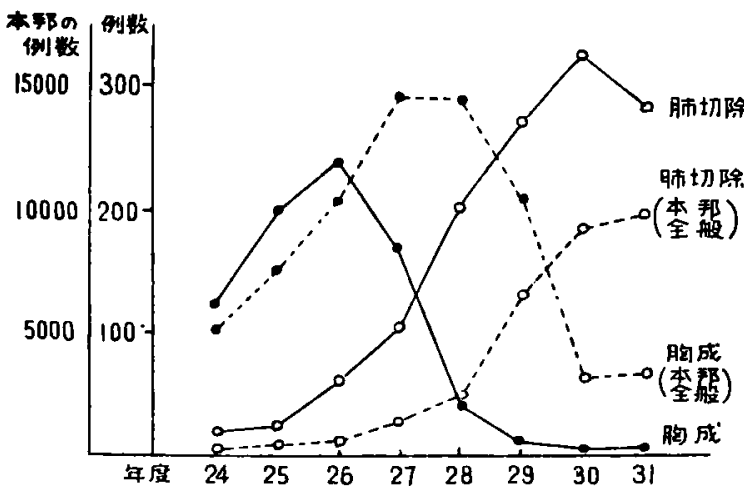

まで急激に增加し，26年を頂点として激減しており， 近来は僅かながら多少增加の傾向が見える. 充填術 はその多発する合併症のため，24年は112例，25年37 例行われたが，以後は全く行わ机ず，之等に対し肺 切除は24年以後逐年增加を远り，30年には最高を示 した．之等の傾向は四1の点線で示す本邦全般の傾 向9）と比較すると，我々のカーブ全体が前にずれて はいるが, 全くよく似た傾向を示している。

2) 性別，年令別

男956 (70.7\%)，女397 (29.396) で，てれを年 度別にみると図 2 の如く，年度別には著明な性別の

図2性別の変嘌

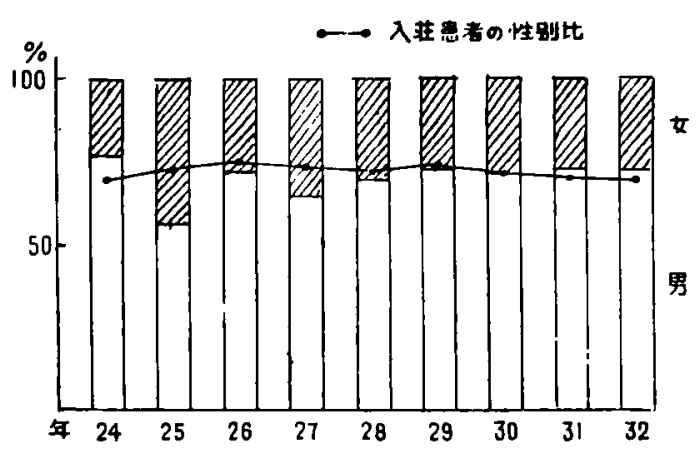

変化はみられない．年度別入所患者の性別比と比較 すると手術例のそれと大体一致している．初期にゃ や不一致が見られるのは，入㾏患者数の膨脹期に当 るためである。

年令層は表 1 の如く，20代が半数近くを占める. 性別比は2.4：1で男が多く，女は男に比し若年者の 手術が多い様である．年度別には図 3 の如く，年と

表 1 年 命

\begin{tabular}{l|r|r|r|r|r|r}
\hline \hline & \multicolumn{2}{|c|}{ 男 } & \multicolumn{2}{|c|}{ 女 } & \multicolumn{2}{|c}{ 計 } \\
\cline { 2 - 7 } & 例数 & $\%$ & 例数 & $\%$ & 例数 & $\%$ \\
\hline 10 代 & 45 & 4.7 & 32 & 8.6 & 77 & 5.7 \\
20 代 & 446 & 46.6 & 204 & 50.7 & 650 & 48.0 \\
30 代 & 300 & 31.4 & 113 & 28.5 & 413 & 30.5 \\
40 代 & 114 & 11.9 & 33 & 8.3 & 147 & 10.9 \\
50 代 & 49 & 5.1 & 14 & 3.5 & 63 & 4.7 \\
60 代 & 2 & 0.2 & 1 & 0.3 & 3 & 0.2 \\
\hline & \multicolumn{2}{|c|}{956} & \multicolumn{2}{|c|}{397} & \multicolumn{2}{|c|}{1353}
\end{tabular}

図 3 年令の年次別変遷

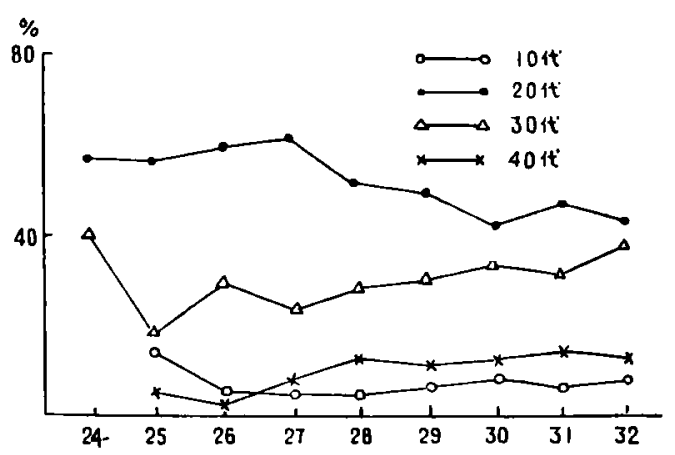

共に20代は減少，他は総て増加の傾向がある，すな わち手術を受ける年令が平均され，漸次高令層，年 少者が増加しているが，との傾向は昨今の肺結核患 者発生の傾向と同様である。

3）全身状態

i) 体重 $40 \mathrm{~kg}$ 以下 $52(3.8 \%), 41 \sim 50 \mathrm{~kg} 543$ (40.1\%), 51 60 kg 627 (46.3\%), $61 \mathrm{~kg}$ 以上131 (9.6\%) であるが，これを比体重で現わすと2.5以 下43 (3.2\%), 2.6 3.0 507 (37.5\%), 3.1 3.5 628 (46.4\%), 3.6 4.0 160 (11.8\%), 4.1以上 15 (1.19) で約85\%は2.6〜3.5である. 年度別に比体 重の推移をみると図 4 の如く，3.1〜3.5は27年まて に上昇して以来各年度間に殆んど差がなく，2.5以 下は少ないが年と共に更に减少して0に近付き，逆 に 3.6 以上は27年以後著明な增加傾向を示す.すな 
図 4 年度別比体量の推移

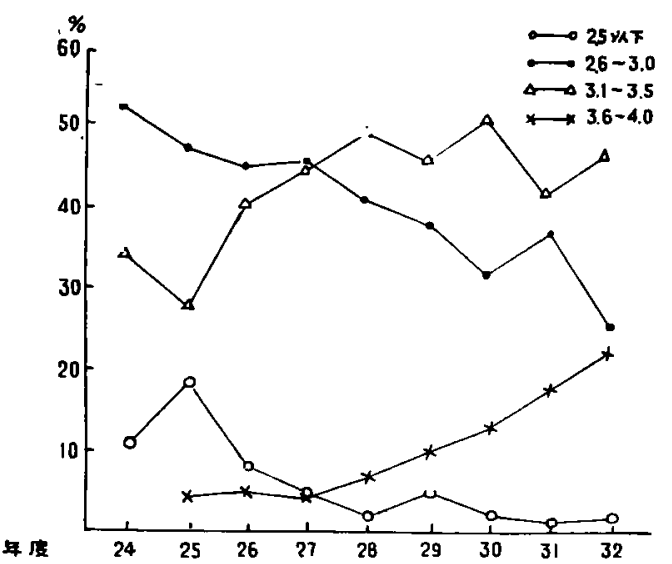

わち一般的に云えば栄善状態は次第に良好になつた と云い得る。

ii）赤沈（1時間值）男 $10 \mathrm{~mm}$ 以下, 女 $15 \mathrm{~mm}$ 以下を正常值, 以下男女共 $20 \mathrm{~mm}$ 迄を柽度促進, 21 50 mm を中等度促進, $51 \mathrm{~mm}$ 以上を高度促進 とすれば, 正常972(71.896), 軽度促進 160 (11.8 \%) 中等度促進177 (13.1\%)，高度促進44 (3.3\%) である. 尚 $101 \mathrm{~mm}$ 以上の高值を示したものが14例 あるが，これらは殆んど昭和26年以前のものて，著 るしく一般状態の悪いもの又は肺穿孔，気管支掼等 のため緊急手術を要したものでる。年度別にみる 之図 5 の如く，正常值は30年迄急激に堌加し以後は

図 5 赤沈 值の変迷

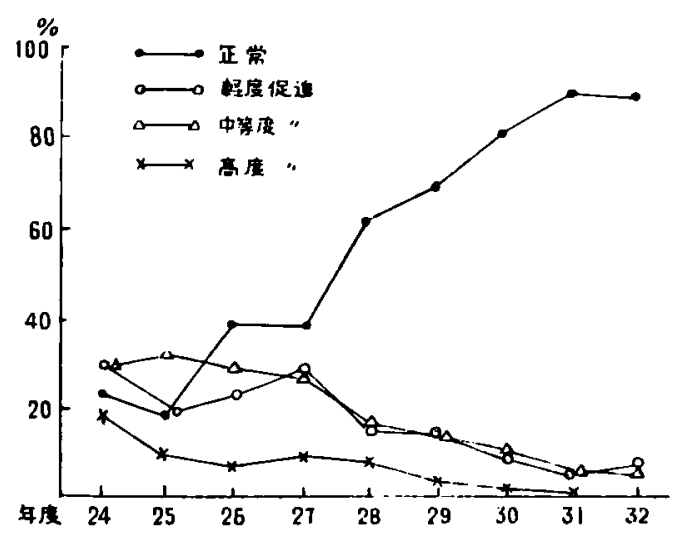

著変なく，他は渐次減少し高度促進は最近はない。

iii）肺活曾及び海老名俻

肺活冒及び海老名值は表 2 の如くである. 肺活量 の年度別推移は図 6 の如く殆んど著明な変化を示 さないか，2000以下は30年頃まで漸次隇少してその 後変化なく，3000以上に多少の増加傾向が見られる.

海老名值 ${ }^{10)}$ は図 7 の如く，Iは多少の増加傾向を， Пは29年迄かなり著るしい増加㑯向とその後の安定
表 2 肺活量及び海老名值

\begin{tabular}{|c|c|c|c|c|c|}
\hline \multicolumn{3}{|c|}{ 肺 活 量 } & \multicolumn{3}{|c|}{ 海 老 名 } \\
\hline & 例数 & 96 & & 例数 & 96 \\
\hline 1000 以下 & 8 & 0.6 & $-51 \%$ 以下 & 113 & 8.4 \\
\hline $1001 \sim 2000$ & 216 & 16.0 & $-31 \sim-50 \%$ & 330 & 24.4 \\
\hline $2001 \sim 3000$ & 476 & 35.2 & $-16 \sim-30 \%$ & 436 & 32.2 \\
\hline $3001 \sim 4000$ & 481 & 35.5 & $0 \sim-15 q 6$ & 348 & 25.7 \\
\hline 4001 以上 & 172 & 12.7 & ブ & 126 & 9.3 \\
\hline
\end{tabular}

困 6 術前肺活量の变遷

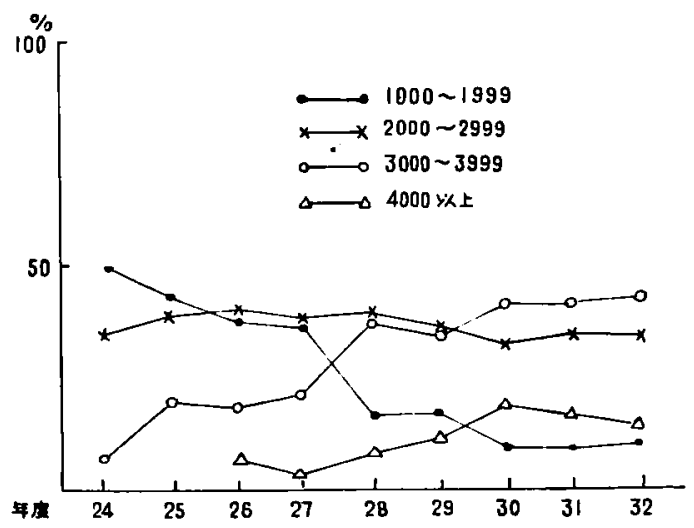

図 7 術前海老名值の变遷

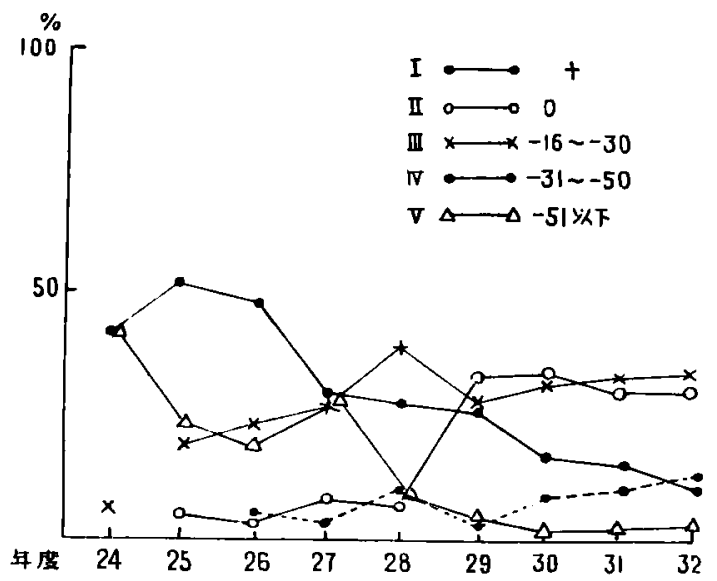

性を示し，III 28年迄の增加㑯向とその後の安定性 を示すが，IVは年次的に絶えず減少傾向があり32年 には既に I，II，III以下となつている．Vは初め殆 んど半数近かつたが，一旦著明に減少し，ての後は 又多少增加の傾向がある。これは近来重症が再び対 象として採りあげられてきたことを意味するが，全 体としては兔す角呼吸機能面において適灾は向上し ているとして差支えない。

\section{第 2 項 術前気管支鏡所見について}

昭和26年より routine の術前検查として気管支 鏡佮査を行つた，総数 1199 例中異常のないむの 725 
(60.4\%)，Samson の分類11) によるI型（非潰痺 性, 非狭䟴性変化すなわ古軽度の充血) 313 (26.1 96), II型 (増殖型すなわちI型より程度の強い充

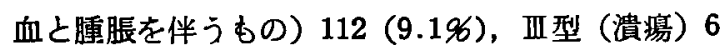
(0.5\%)，IV型（般店性狭窄） $43(3.8 \%)$ である. I 型はこれを正常籁囲とすれば1039 (86.6\%) は正 常である、III型が6例あるが，てれは総て28年以前 の適応の誤りで，手術迄の約 1 ケ月内に軽快するこ とを予像して行つたあのであり，29年以後は化学療 法によりI又はIV型への移行を確認してから手術を 行つた. 今II， III, IV型を有所見者とすると性別有 所見者の推移は図 8 の如く，26年以後は著明に減少

図8 年度別気管支鏡有所見者の推移

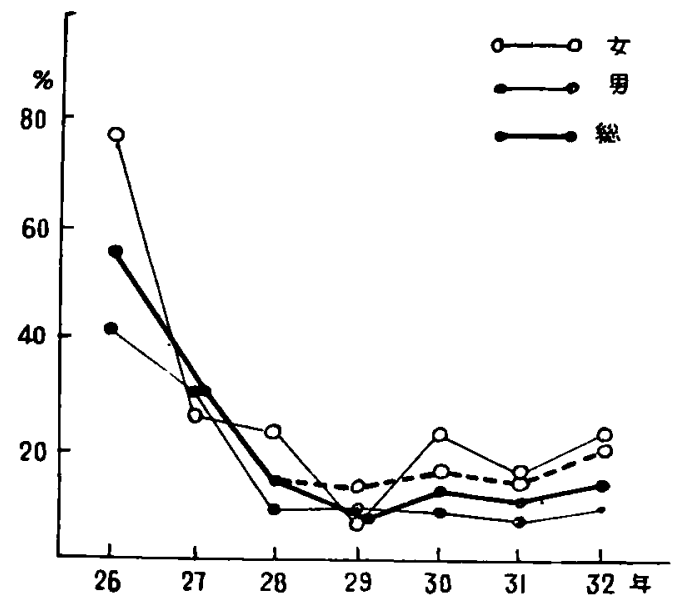

している如くみえるが，これは術前化学療法を充分 行いII型, III型は他の型に移行せしぬたためで，以 上の有所見者の他に37例は最初の検査ではII型以上 の変化がみられた. これを加えると秎数は点線の如 き推移を示し，28年以後減少をみないのみか多少增 加の傾向がある。

第 3 項 術前 $X$ 線所見について

$\mathrm{X}$ 線所見の分類は孷密に行えば甚だ煩劕であるが， 凡その傾向を見るため空洞性透宽の有然に大别する と，透亮あり 863 (63.8\%)，無し 490 (36.2\%). て ある。これを年度別にみると図 9 の如く，26年迄は 80\%以上透亮影があり以後漸次減少の傾向て31年は 54.196となるか，32年度は又少し增加している．化 学寮法以前の治療に関係するあのとして虚脱療法不 成功例を，治瘾し難い比較的重症を意味するものと して巨大空洞（X線写真上透亮の径 $5 \mathrm{~cm}$ 以上）を, 安定した病巣を代表するものとして結核董，硬化性 病巣を選んで年度別にその頻度の変遷をみると図10 の如く, 結核腫, 便化性病栄は29年頃より急激に增
図 $9 \times$ 線上透亮の有無

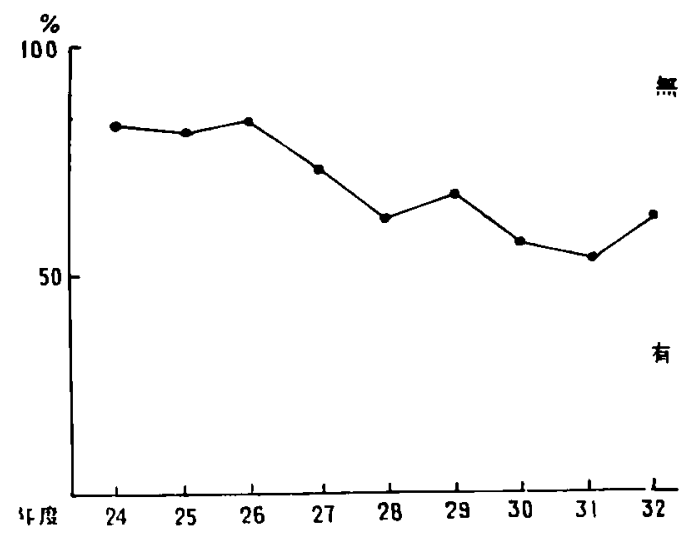

図10 X楾的適忍症の変要

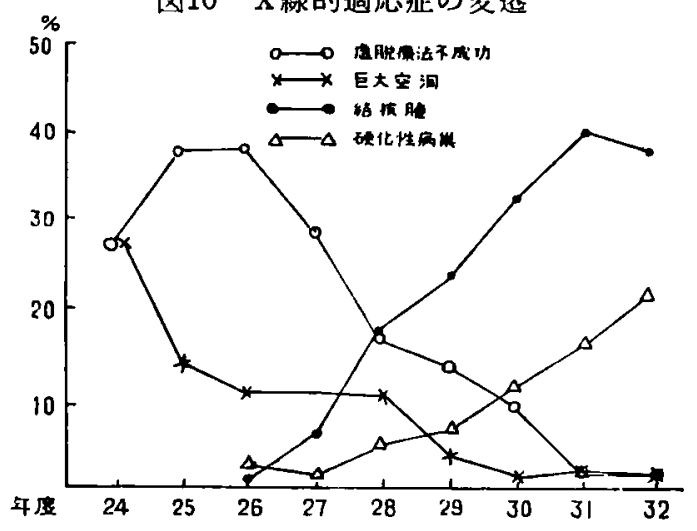

加し，虚脱療法不成功の減少は虚脱療法そのものが 少くなつた事之，彷前にあつたものが夫々処理され 終つたためと考えら机，巨大空洞はむし発生してあ 化学療法により帤く消失又は縮少するか稀なものに なつて来た：之を図 9 の現うす所と介して考虑する と適応は概して好忶していて巨大空洞等は少くなつ たか，化学療法によつてもなお邀残空洞例は跡を絶 たないことを芯味する。

厚生省病型分類12) に彷う之， III型92 (6.8\%)， IV型 492 (36.3\%)，V 型 266 (19.7\%)，VII 型 503 (37.2\%) である. これを年度別にみると図11の如

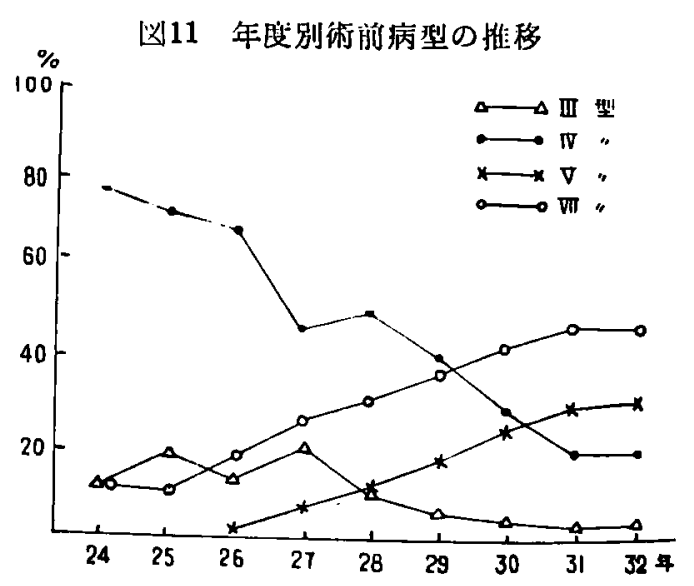


く，IV型，II型は年と共に減少し，V型，VII型は増 加している. 結核腫に虚脱療法や化学療法は効少く， その小なるものは故置しても増悪率は比校的少く， これに対する肺葉切除は機能上の損失が高価である が、区域切除や部分切除の手技が確立され，術後の 呼吸機能の障碍も最小となし得る様になつてから手 術例数は急激に増加した。硬化性病巣, 混合型結核 が增加したのは, 術前に化学療法が徹底的に行われ る為と思われる。但し31年以後は殆んど変化が認め られない。

\section{第 4 項 排菌状態}

肺切除術の成績は術前の排菌状態汇関係すると云 われ，菌陰性の状態で手術するととが望ましいので あるが，化学㙩法を行つても排菌が止まないこと自 体が手術を必要とする理由であるし，なおその様な 場合は早く又高度の耐性を獀得し手術を益々困難に することもある. 従つて排菌の状態というあのは適 応上甚だ重要な事項である.

術前 6 ケ月以内の排菌をみると，墔抹，培養共陽 性407（30.196)，鉒抹陽性，培養陰性173 (12.8\%)，

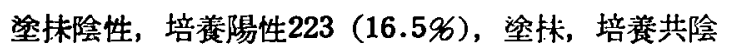
性550 (40.6\%) で陽性者の方が多い, 術前 3 ケ月 以内では淕抹，培養共陰性は596 (44.0\%) となる。 術前 6 ケ月以内の排菌群（塗抹，培羡共陽性及び塗 抹陽性, 培養陰性は塗抹陽性とし，塗抹陰性，培盖 陽性のむののみ培養陽性とした）を年度別にみると 図12の如く，陽性率は30年迄は念汇減少し，特に筀

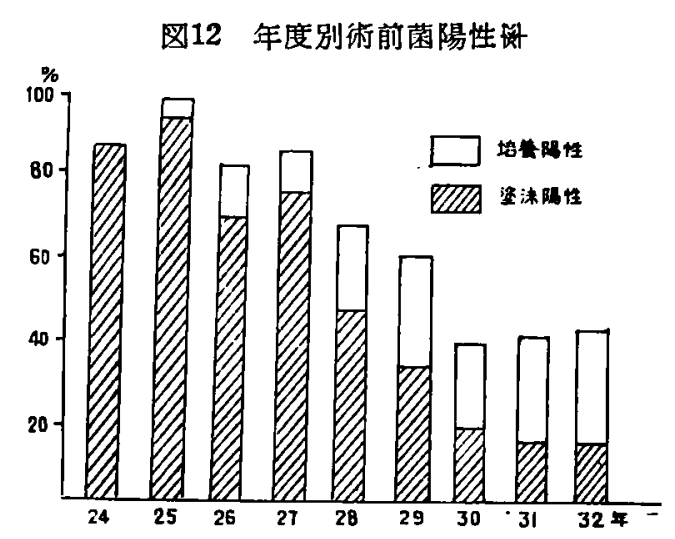

抹陽性において顕著であるか，30年以後は全陽性率 及び塗抹陽性，培養陽性の比率任殆んど変化がみら れない，乙机は化学療法の発達が大なる関係を有す と思われるか，なお比較的軽症が手術の対象となつ て来たことによる. し加し一面化学療法の能力にも 限界があるととを示すすのである。

Raleigh の所謂 target point13) 亿達して手術を
行つたものは281例であるが，年度別には図13の如 図13 targstrgt poit 到達例

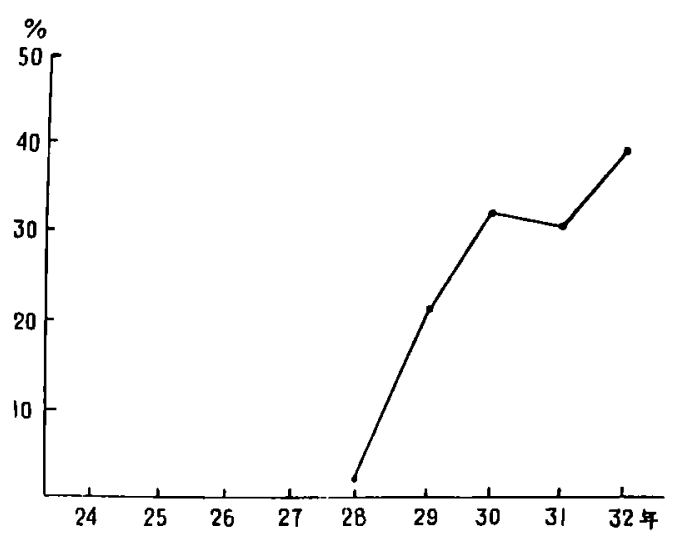

く，28年に5 例みられてより 30 年迄急激に增加する が，その後は著朋な変化がみられない，30年以後に おける target point に達しないあのはその後長期 間化学療法を続けてあ恐らくそれ澾しないるのが 大多数であると思われる.

症例の術式別之陽性率の関係をみると表 3 の如く，

表 3 術式別術前検痰成綪例数

\begin{tabular}{|c|c|c|c|}
\hline & & 例 数 & $\mathscr{6}$ \\
\hline \multirow{3}{*}{$\begin{array}{c}\text { 全 切 除 } \\
95\end{array}$} & 前沫陽性 & 75 & 78.9 \\
\hline & 培羕陽性 & 9 & 9.5 \\
\hline & 培養陰性 & 11 & 11.6 \\
\hline \multirow{3}{*}{$\begin{array}{c}\text { 肺槊切除 } \\
516\end{array}$} & 洤沫陽性 & 309 & 59.9 \\
\hline & 培食陽性 & 85 & 16.5 \\
\hline & 培養陰性 & 122 & 23.6 \\
\hline \multirow{3}{*}{$\begin{array}{c}\text { 区 域切 除 } \\
742\end{array}$} & 望沫陽性 & 196 & 26.4 \\
\hline & 培養陽性 & 129 & 17.4 \\
\hline & 培養陰性 & 417 & 56.2 \\
\hline
\end{tabular}

全切除が88.4\%で最も陽性率が高く，区域切除が最 も低いが，病坚の搪がりからして当然であろう。 昭和27年以降，薬剂耐性検査を行つたか，その結 果の判明したものは表 4 の如くである.（完全耐性 のみをとつた). Streptomycin (以下 SM と略す) $10 \gamma$ 以上, Paraamino-salicylic acid (以下 PAS 表 4 薬 剂 耐性

\begin{tabular}{l|c|c|c|c}
\hline & $0 \gamma$ & $1 \gamma$ & $10 \gamma$ & $100 \gamma$ \\
\hline SM & 21 & 137 & 72 & 36 \\
INH & 96 & 26 & 15 & 14 \\
PAS & 50 & 23 & 36 & 63
\end{tabular}


と略す) $100 \gamma$ 以上. Isonicotic acid hidrazid (以 下 JNH と略す.) $1 \gamma$ 以上を耐性ありとし，年度 別に耐性発現率をみると図14の如く，年と共に耐性

図14 年度別薬剂耐性発現率

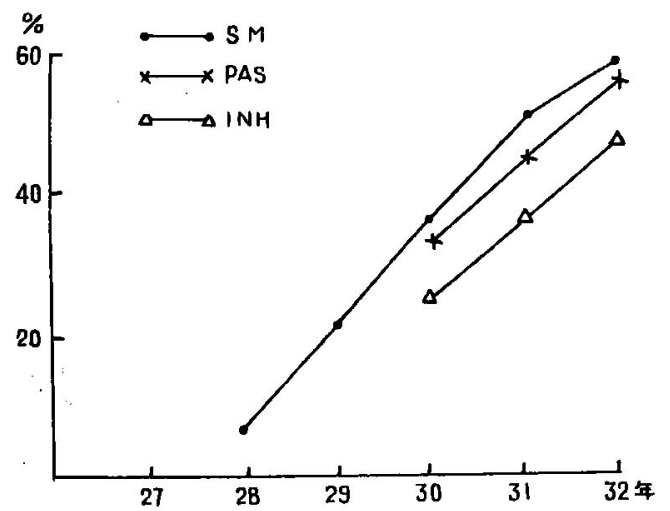

発現率は急激に増加し，32年は SM，PAS には50 负以上，1NH には40\%以上が耐性菌である。

第 5 項 発病又は発見より手術迄の期間 発病又は発見より手術迄の期間は表 5 の如く，発

表 5 発病又は発見より手術迄の期間

\begin{tabular}{ccc|cc|c}
\hline \multicolumn{1}{c|}{ 期 } & 間 & 例 & 数 & \% \\
\hline 1. & 年 & 以 & 内 & 335 & 24.7 \\
1 & $\sim$ & 3 & 年 & 741 & 54.8 \\
3 & $\sim$ & 5 & 年 & 135 & 10.0 \\
5 & 年 & 以 & 上 & 142 & 10.5
\end{tabular}

病後 1〜3 年の間に手術を受けるものが多いが，こ れを年度別にみると図15の如く，発病後 1 年以内に

図15手術迄の期間

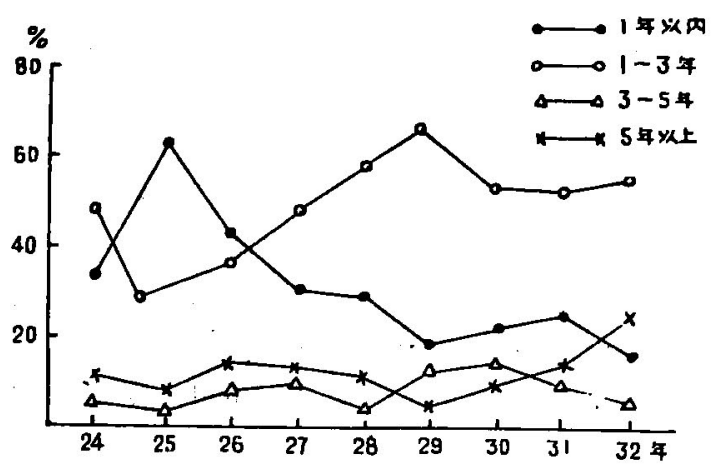

手術したものは初期に比較的多く，29年以後は20\% 前後となつた. $1 \sim 3$ 年は各年度毎には一定の傾向 を示さないが, 前半, 後半に分ければ後半では增加 している. 5 年以上経過したものも大体同様で， 3 〜 5 年を加えても一定の傾向を示さず, 㧧いていえ
ば30年以後やや増加する傾向がある，発病後手術迄 の期間が長くなつているのは術前の化学療法を充分 行なう，あるいは化学療法に頼りすぎるという一般 的傾向によるもので，特に長期に亘るすのは長期化 学療法後の再発, 無計画な長期化学㙩法の失敗, 広 笽な病巣がそれにより改善されて漸く手術適応まで に到つたもの等が増加した故である。

\section{第3章 化学療法について}

初期は SM 入手困困難で全く使用しないか又は少 量を不規則に使用したが，その後一般の化学療法の 発達と共に術前後の化学療法も急速に変化した. 術 前術後に行なう化学療法の変遷は図16の如く，初期

\section{図16 化学療法の変選}

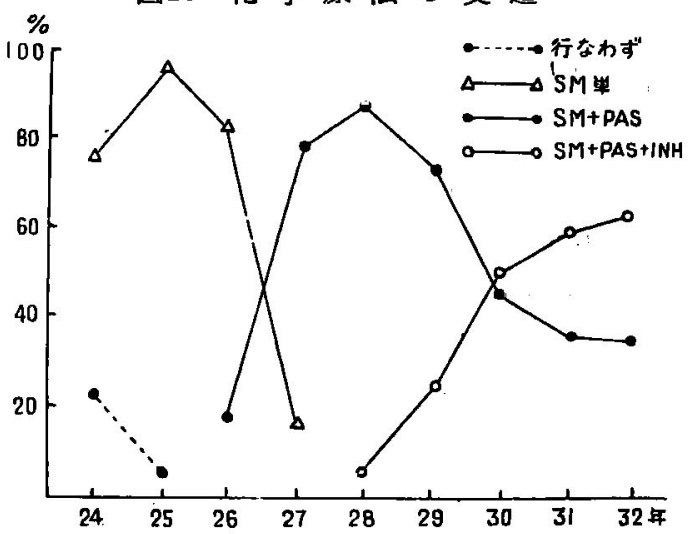

は SM 单独使用が, 27 年より SM, PAS 併用が, 29年より SM，PAS，INH 3 者併用が多い，30年 以後は年次的に化学療法の方法に甚しい変化がみら れない.なお Viomycin と Pyrazinamid は使用さ れていない.

術前後の計画的化学療法施行期間は図17の如く，

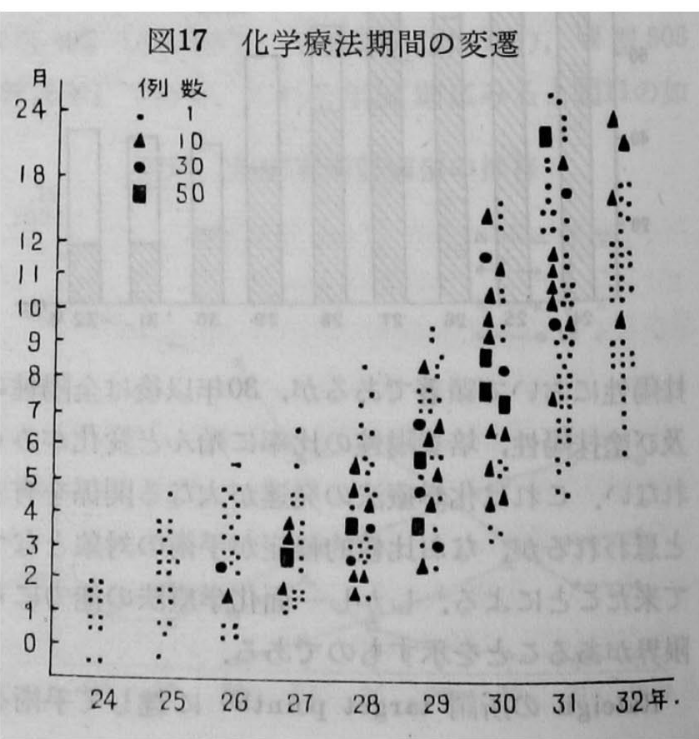


年と共に化学症法を長期間行う様になり，28年以前 は 8 ケ月以上行つたものはなく，1 年以上行つたも のは30年には僅かに4.096であるが，31年には43.6 \%, 32年には48.7\%となつた。

入所前に行われた化学療法の量を，その代表とし て SM のみについて年度別にみると図18の如く，

図18 入所前に於ける SM 使用量

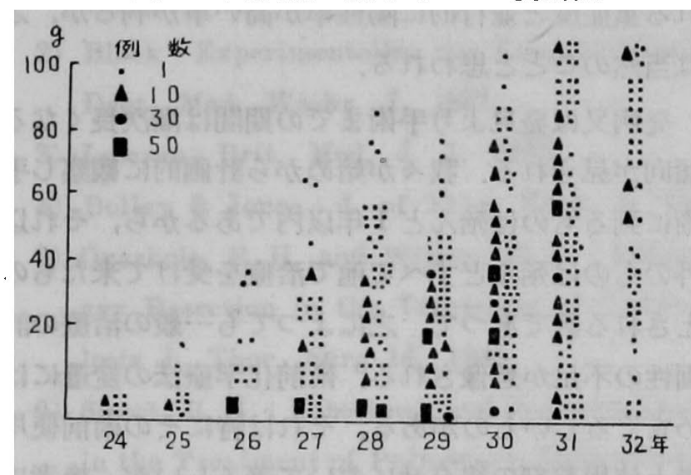

化学療法の発達と共に入所前のSM 使用量も増加し, $51 \mathrm{~g}$ 以上使用は 28年5.7\%，29年 $1.5 \% ， 30$ 年 17.5 并, 31年48.9\%，32年71.196 急激に増加してい る.

術前の計画的化学療法を SM 使用量によつてみる と図19の如く，29年以前は $20 \mathrm{~g}$ 以下が過半数を占

\section{図19 術前計画的 SM 使用量}

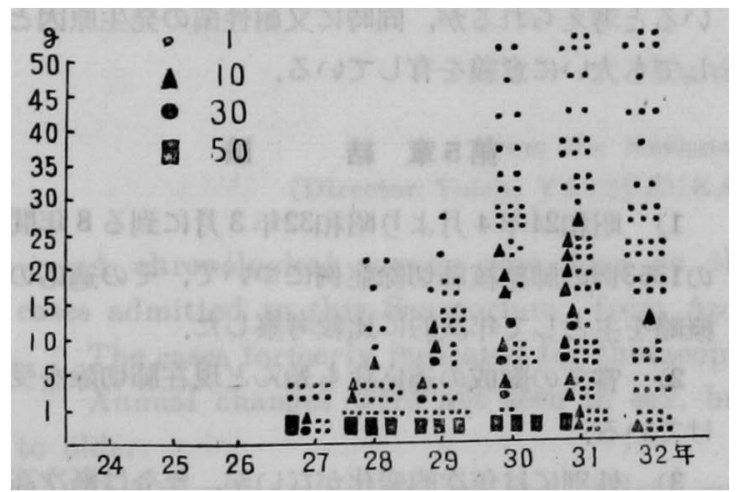

めるが，30年は21 40 $\mathrm{g}$ が59.6\%，31年は31〜 $50 \mathrm{~g}$ が51.3\%，32年は31 60 g かi52.0\% と 30 年迄は急 激に，以後比校的徐々に増加している，尚この数に は SM を使用せず，SM 以外の抗生物質で化学療 法を行つたものは含まれていない．

INH 使用量をみると図20の如く，26年以前には 全く使用例をみず，27年は7.8\%に使用したか，い づれも $5 \mathrm{~g}$ 以下である. $11 \mathrm{~g}$ 以上使用例数は28年 $2.5 \%, 29$ 年9.6\%, 30年25.8\%,31年44.8\%, 32年 55.2\% と渐次增加の傾向がみられる.

術後化学㓐法の期間は四21の如く，渐次長期間行
四20 術前 INH 使用量

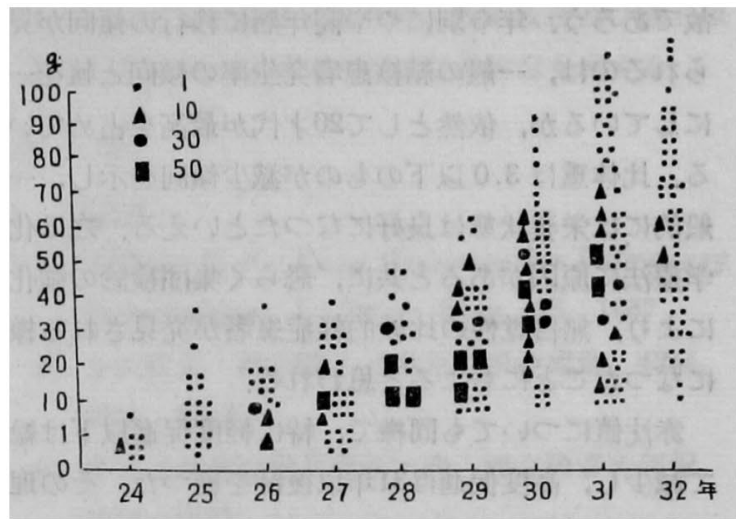

図21 術後化学療期間の変遷

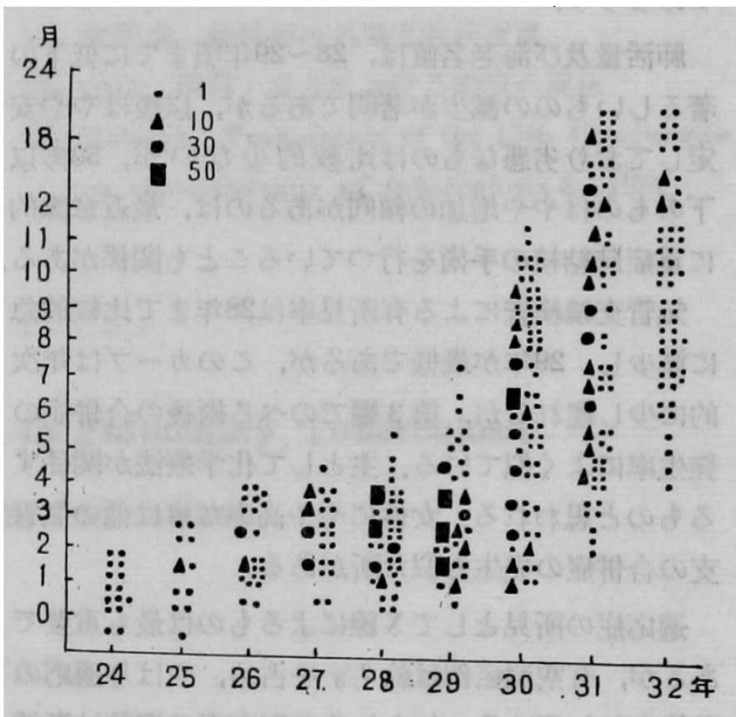

なう様になつたがその傾向は特に30年以後著明であ る.

\section{第4章 答括}

初めに述ベた様に，肺結核の治療として肺切除が 再び採り上げられたのは，外科的虚脱療法の能力の 限界が明らかになつたからである. 従つて後に触れ るが，初めは虚脱療法適応外の巨大空洞や広汎高度 の実質性変化を伴なう症例が切除の対象となつたか， 胸成術が肺尖部の小空洞を処理するのに少くとも $\mathbf{5}$ 本の助骨切除を必要として機能の情牲が大きいのに 反し，肺切除の技術の進歩と合併症の减少により， その様なものの処理は安全確実であり且機能の犠牲 が少ない所から，胸成適底症が肺切除に移行した。

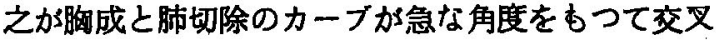
した理由であろう.

性別には年次的に殆んど変化がない，入荘患者の 性別比と殆んど差がないのは，患者が原則的に手術 
を希望して又はそれをすすめら机て来たあのである 故であろう．年令別にやや高年層に移行の傾向が見 られるのは，一般の結核患者発生率の傾向之軌を一 にしているが，依然として20才代が最高を占めてい る. 比体重は 3.0 以下のものが減少傾向を示し, 一 般的には栄養状態は良好になつたといえる，之は化 学療法に原因があると共に，恐らく集団検診の強化 により，無自覚性の比較的軽症患者加発見される様 になつたてとにあよると思わ机る。

赤沈值についてあ同様で, 特に軽度促進以下は総 て隇少し, 高度促進は31年以後跡を絶つた，二の理 由も前記栄美状態の変遷と同様な理由に基づくもの であろうう.

肺活量及び海老名值は，28〜29年頃までに低下の 著るしいものの減少が著明であるが，以後はやや安 定しており劣悪なものは比較的少ないが，50\%以 下のむのはやや增加の傾向があるのは，最近忩識的 に重症肺結核の手術を行つていることも関係がある。

気管支鏡検査による有所見率は28年まで比較的急 に減少し，29年が最低であるが，とのカーブは年次 的任少し遅れるが，第 3 編でのべる術後の合併症の 発生率によく似ている. 主として化学療法が関係す るものと思われる，女性にやや高率な事は他の気管 支の合併症の発生之似た所がある.

適応症の所見としてX線によるものは最も重要で あるが, 有空洞症例は約 $2 / 3$ を占め, やはり適応の

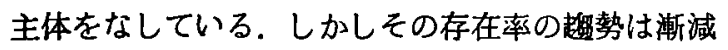
して後には $1 / 2$ となり，然もそのうち初期に多かつ た巨大空洞著るしく減少しており，之に反して結 核腫等の安定した病巣例加增加している，虚脱療法 不成功例が著诚しているのは勿論最近行われる症例 が少いことや，當て存在した症例の始末が大部分終 つたととを意味するものであろう，ともかく，空洞 症例は末だ跡を絶たずなお $1 / 2$ に及ぶが，一般に適 応は良好になつたことは事実である。方同じく重 要な意義を持つ排菌については，藏陽性率は空洞の 存在率よりやや低いがほぼ同様な率を占めている. しかし年次的に空洞の存在率よりは急な傾斜を以つ て減少しており，30年以後は殆んど変化がないか， そのうち培養陽性のあのの方が多い率を占める。 し かし術前 3 ケ月以内と 6 ケ月以内の陰性率は 4 \%し か差がない事は，菌の陰性化が初回化学療法におい て3ケ月から6ケ月の間に大部分見られる事と，乙 の群の前半に化学療法の不允分なむのを念む事実か ら，少なくとも後半の群では菌陰性化についてはえ
れ以上の化学療法が効果がない事を示すものではあ ろう. この点から, 当然, target point 到達もそれ 等においては期待し難いと考えられる訳であるか， target point 例は28年以後增加傾向にあり,之は 化学療法の効果と共に，発見される症例自身にあよ るむのと考えられる。

術式別に菌陽性率を見ると，それによつて推定さ 机る重症度之並行的に陽性率が高い事が判るが，之 は当然のととと思われる。

発病又は発見より手術までの期間は漸次長くなる 傾向が見られる.我々が始めから計画的に観察し手 術に到るむのは殆んど 1 年以内であるから，それ以 外のものは殆んどすへて他で治療を受けて来たもの とされる訳であつて，之によつてあ一般の治療の計 画性の不足が想像される，術前化学療法の变遷には めまぐるしいものがある．それは特にその術前使用 量と使用薬剂の組合せにおいて著るしいか，後者に ついては30年以後は比較的安定しており，3者併用 が大部分を占めている.

術前の抗結校郕の使用量は，入所前のものも，入 所後の計画的なむのも著るしく堌加し，特にそれが 30年以後に甚だしい. 之は当然化学療法の期間の長 期化と相伴なうあのであり，又以上述へた項目にす ベて関聯して影響を与えて適応症の改善に貢献して いると考えられるが，同時に又耐性菌の発生原因と しても大いに意義を有している。

\section{第 5 章 結 論}

1) 昭和 24 年 4 月上り昭和 32 年 3 月に到る 8 年間 の1353例の肺結核肺切除症例について，その適応の 概略を主として年次的に比較考察した.

2）賞ての胸成の適応症む殆んど現在肺切除を受 けている.

3）性別には年次的変化がないが，年令は漸次高 年に移行の傾向がある.

4）術前一般状態は著るしい改善の道を辿つたか， 最近は殆んどこの極限に達している。

5） X 線所見むよく年次的に改善されているが， 尚約半数は空洞を有しこれ等は化学療法を受けてあ 改善の期待が少ない。

6) 喀痰中藏陽性率屯年次的に改善されている加， 之以上の化学療法によつて改善さ㧈る期待は少なく， 逆に耐性菡発現率は増加の傾向にある。

7）発病又は発見より手術までの期間は尚長期化 の傾向にある. 
8）術前化学療法は初めの SM 単独より PAS 併用，更に 3 者併用へと移行し，その使用量，施用 期間は著るしく增して尚增加の傾向がある。

1) Gluck, T. ' Experimenteller Beitrag zur Frage der Lungenexstirpation. Berl. klin. Wschrft. 18, 1881.

2) Block : Experimentelles zur Lungenresektion. Deut. Med. Wschr. 7, 1881.

3) Low son : Brit. Med. J. 1, 1893.

4) Dolley \& Jonea : J. of Thor. Surg. 8, 1939

5) Overholt, R. H. and Wilson, N. J. : Pulmonary Resection in the Treatment of Tuberculosis J. Thor. Surg 14, 1945.

6) Sweet, R. H. : Lobectomy and Pneumonectomy in the Treatment of Pulmonary Tuberculosis; A Subsegment Report, J. Thor. Surg. 19,

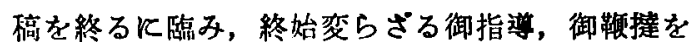
赐つた岡山大学律田名誉教授，砂田教授及び国立療 羡所山陽荘長八塚博士に深甚なる謝意を表する。

文献

1950.

7) Bailey, C. P. : Lung Resection for Pulmonary Tuderculosis. J. Thor. Surg. 15, 1947.

8）小沢凱夫：肺切除. 日本外科学会雑誌, 42回, 12 号, 1942.

9）厚生省医柊局国立療養所課：国立療養所年報， 昭24 昭32.

10）小野勝：呼吸機能検查法。

11）牧野進：肺結核の気管支鏡検査法.

12）山口，隈部 日本飞括ける結核の現状。

13) Raleigh : Transaction of the 13th Comference on chemotherapy of tuberculosis 2, 1954.

\title{
Statistical Survy on Resection in Pulmonary Tuberculosis
}

Part I. On the Indication

\author{
By \\ Kunio TADA \\ from the National Sanatorium Sanyoso \\ (Director: Yoichi YATSUZUKA, M. D., Chief of the Sanatorium)
}

A chronological survey was done on the operation for pulmonary tuberculosis in 1353 cases admitted to this Sanatorium, from April 1949 to March 1947.

The cases formerly indicated for thoracoplasty were mostly undergone pulmonary resections.

Annual changes were not seen in sex, but ago distribution, tended to shift from younger to older.

Preoperative condition of the patient was gradually improved, and reached to its limit recently.

The condition roentgenological was improved annually, though, almost one half of the cases had cavities which were less expected to being improved by chemotherapy.

The positive cases of tuberculous bacilli in sputa were getting decreased in number, without any expectations for improving by subsequent ohemotherapy. By the way, occurrence of resistant bacilli was increased in a sense.

Duration from onset to operation was increase.

Preoperative chemotherapy was shifted use of streptomycin, PAS and INAH instead of single use, and the dosage and duration were tended to increase. 